\title{
Imaging pattern of radiolabelled lymphokine-activated killer cells in patients with metastatic malignant melanoma
}

\author{
Erwin Schäfer ${ }^{1}$, Reinhard Dummer ${ }^{2}$, Christoph Eilles ${ }^{1}$, Wilhelm Börner ${ }^{1}$, Roland Martin ${ }^{3}$, \\ Johann Rendl', and Günter Burg ${ }^{2}$ \\ ${ }^{1}$ Department of Nuclear Medicine, ${ }^{2}$ Department of Dermatology, ${ }^{3}$ Department of Neurology, \\ University of Würzburg, Josef-Schneider-Strasse 2, D-8700 Würzburg, Federal Republic of Germany
}

Received 2 April and in revised form 20 August 1990

\begin{abstract}
In patients with metastatic malignant melanoma the distribution patterns of radiolabelled lymphokine-activated killer (LAK) cells were investigated. Peripheral mononuclear cells (PMC) were isolated from six patients. LAK cells were generated by culturing PMC in complete medium containing $1000 \mathrm{U}$ interleukin (IL)$2 / \mathrm{ml}$ and labelled with indium 111 before retransfer. We obtained scans at $2.5,24,48$ or $96 \mathrm{~h}$ after injection with a high resolution gamma-camera. Intravenously injected LAK cells distributed to the lungs, liver, spleen and bone marrow. External tumour detection of known lymph node and bone metastases was successful in four. It failed in one patient with a solitary lung metastasis and in another patient with subcutaneous metastases. Our results suggest that LAK cells show tumour homing, providing a direct interaction between tumour and cytotoxic cells. We conclude that PMC seem to retain their ability to migrate after IL-2 stimulation and ${ }^{111}$ In-labelling. This technique may be helpful for kinetics studies or external detection of metastases in patients with malignant melanoma.
\end{abstract}

Key words: Interleukin-2 - Tumour homing - Lymphokine-activated killer cell migration - Malignant melanoma - Cell labelling

Eur J Nucl Med (1991) 18:106-110

\section{Introduction}

The co-culture of normal peripheral blood lymphocytes (PBL) with interleukin-2 (IL-2) results in the generation of cytotoxic cells having broad anti-tumour activity.

Offprint requests to: $\mathrm{E}$. Schäfer
These lymphokine-activated killer (LAK) cells are capable of destroying a variety of target cells, including cultured and fresh autologous solid tumours, allogeneic and xenogeneic tumour cells and leukaemic blasts. The cytotoxic activity of LAK cells is not restricted to products of the major histocompatibility complex, and fresh uncultured normal cells are, for the most part, resistant to LAK lysis (Grimm et al. 1982).

Several clinical studies indicate that adoptive immunotherapy with LAK cells (Rosenberg et al. 1987) or tumour-infiltrating lymphocytes (TIL) (Topalian et al. 1988) and IL-2 can achieve consistent and reproducible anti-tumour effects. It is questionable whether this effect is mediated by indirect mechanisms such as the induction of other cytokines or direct cell-mediated cytotoxicity. More recently, the ability of TILs to traffic and localise at tumour sites was demonstrated after pretreatment with cyclophosphamide and IL-2 infusion (Fisher et al. 1989). Previous efforts to traffic radiolabelled LAK cells in patients with cancer of various origins failed (Lotze et al. 1980; Mukherji et al. 1988), or they showed poor enrichment at the tumour site in comparison with specifically tumour antigen-sensitised killer cells (Mazumber et al. 1984).

In the present study we report the results of in vivo localisation of LAK cells. Our observations indicate that LAK cells are capable of localising at tumour sites in patients with malignant melanoma. No immunosuppression or additional IL-2 infusion is necessary for this lymphocyte traffic.

\section{Patients and methods}

Patients. The protocol was approved by the Committee of Medical Ethics of the Medical Faculty of the University of Würzburg. Patients with malignant melanoma after giving written consent were eligible. Tumour sites included the lung, inguinal and axillary 
lymph nodes, subcutaneous and bone metastasis. The tumour sites were documented by computed-tomography (CT) scan and ultrasonic examination. Following LAK cell infusion, the metastasis was histologically confirmed in five of six patients. According to the clinical situations some patients were included in a clinical trial using IL-2.

Preparation of LAK cells and radiolabelling. Peripheral blood was sampled by vein puncture $(160 \mathrm{ml})$ in five patients; in one patient peripheral blood mononuclear cells (PMC) were collected by leucapheresis (Haemonetics V 50). The flow rate was $60-70 \mathrm{ml} / \mathrm{min}$, and during $4 \mathrm{~h}$ a blood volume of 10-12 1 was processed.

After separation by Ficoll-Hypaque centrifugation, PMC were cultured at $0.5 \times 10^{6}$ cells $/ \mathrm{ml}$ in complete medium $(\mathrm{CM})$ consisting of RPMI 1640 plus $10 \%$ human serum, $100 \mathrm{U} / \mathrm{ml}$ penicillin, $100 \mathrm{U} /$ $\mathrm{ml}$ streptomycin, $50 \mu \mathrm{g} / \mathrm{ml}$ gentamycin and $1000 \mathrm{IU} / \mathrm{ml} \mathrm{IL-2} \mathrm{(Pro-}$ leukin, Cetus) for 4 days at $37^{\circ} \mathrm{C}$ at a humidity of $5 \% \mathrm{CO}_{2}$. After harvesting and washing three times PMC were incubated with $7.5 \mathrm{MBq}$ indium 111 oxine in $4 \mathrm{ml}$ PBS for $15 \mathrm{~min}$ at $37^{\circ} \mathrm{C}$. Viability was assessed by trypan blue dye exclusion. Labelling efficacy was calculated from the dose calibrator measurements of radioactivity of the cell suspension during incubation (total added activity) and after labelling (final activity)as follows:

Labelling efficacy $(\%)=\frac{\text { final activity }(\mathrm{MBq})}{\text { total added activity }(\mathrm{MBq})} \times 100$.

Finally, cells were washed twice and transferred into $250 \mathrm{ml}$ normal saline and re-transfused within $30 \mathrm{~min}$ without, additional IL-2 or immunosuppressive agents. Prior to transfusion the labelled LAK cells were filtered by passing the cell suspension through a standard blood tubing set containing a $200-\mu \mathrm{m}$ in-line filter. Static gamma-camera imaging was obtained at $2.5,24$ and 48 or $96 \mathrm{~h}$ using a gamma-camera (GE 400 AT ZS) equipped with a lowenergy collimator. The window was centered over the $173 \mathrm{keV}$ photopeak of ${ }^{111} \mathrm{In}$. Anterior and posterior chest, abdomen, pelvis and skull, which were known to be clinically involved, were imaged. Counts per pixel were calculated with the regions of interest technique at tumour sites and compared with the corresponding uninvolved side.

\section{Results}

Six men with metastatic malignant melanoma received ${ }^{111}$ In-radiolabelled LAK cells. The amount of ${ }^{111} \mathrm{In}$ activity per number of applied cells ranged from 0.67 to $5.2 \mathrm{MBq} / 10^{8}$ cells and the total infused activity, from 4.8 to $6.5 \mathrm{MBq}$. The data of re-transfused cells, viability and labelling efficacy for all six patients are shown in Table 1. LAK cell injection was well tolerated. Only in three patients were transient fever with a maximum of $38.5^{\circ} \mathrm{C}$ and slight chills observed, leading to no specific treatment.

Re-transfused cells distributed primarily to the lungs, spleen and liver with minimal uptake in bone. After $24 \mathrm{~h}$ the liver and spleen showed a slight increase, whereas the greater amount of the activity in the lung decreased (data not shown). The mean concentration per pixel in the spleen was 1.5 times greater than in the liver although the total activity in the liver was greater.
Table 1. Patients and re-transferred LAK cells characteristics

\begin{tabular}{lcccc}
\hline Patient & Age/sex & $\begin{array}{l}\text { Labelled } \\
\text { cells } \\
\text { infused }\end{array}$ & $\begin{array}{l}\text { Viability } \\
(\%)\end{array}$ & $\begin{array}{l}\text { Labelling } \\
\text { efficacy } \\
(\%)\end{array}$ \\
\hline 1 & $35 / \mathrm{m}$ & $5 \times 10^{8}$ & $\geq 95$ & 88 \\
2 & $69 / \mathrm{m}$ & $1.6 \times 10^{8}$ & 80 & 76 \\
3 & $76 / \mathrm{m}$ & $1 \times 10^{8}$ & 75 & 60 \\
4 & $42 / \mathrm{m}$ & $3 \times 10^{8}$ & 90 & 65 \\
5 & $54 / \mathrm{m}$ & $8 \times 10^{8}$ & $\geq 95$ & 75 \\
6 & $52 / \mathrm{m}$ & $1.6 \times 10^{8}$ & 94 & 74 \\
\hline
\end{tabular}

Table 2. Relative uptake of ${ }^{111}$ In compared with the contralateral side measured scintigraphically

\begin{tabular}{lllllll}
\hline \multirow{2}{*}{ Patients } & $\begin{array}{l}\text { Tumor } \\
\text { sites }\end{array}$ & $\begin{array}{l}\text { Localiza- } \\
\text { tion by } \\
\text { scintiscan }\end{array}$ & \multicolumn{4}{l}{ Relative uptake (\%) } \\
\cline { 5 - 7 } & & & 2.5 & 24 & 48 & 96 p.i. \\
\hline 1 & L lung & - & - & - & - & n.d. \\
2 & R femur & + & - & 1.6 & n.d. & 1.5 \\
& R axilla & + & - & 1.2 & n.d. & 1.4 \\
3 & R groin & + & - & 1.5 & 1.6 & n.d. \\
4 & R axilla & + & n.d. & 1.4 & n.d. & n.d. \\
5 & R groin & + & 1.3 & 1.55 & 1.44 & n.d. \\
6 & Sub- & - & - & - & - & n.d. \\
& cutaneous & & & & & \\
\hline
\end{tabular}

- not detectable; n.d., not done; R, right; L, left; p.i., postinfusion

In four of six patients, who underwent gamma-camera scintigraphy, images demonstrated an enrichment of radiolabelled LAK cells at tumour sites, including those in the lymph nodes, visceral masses and bones, as verified by CT or ultrasonic and histological examination. Tumour detection failed in one patient with a single lung metastasis and in another with subcutaneous tumour sites (Table 2). Tumour visualization was mainly obtained between 24 and $48 \mathrm{~h}$ post-infusion. In only one patient was tumour uptake seen as early as $2.5 \mathrm{~h}$ postinfusion (Patient 5). The kinetics of tumour localisation in this patient with an inguinal mass is shown in Fig. 1. Figure 2 demonstrates in another patient a chain of involved lymph nodes extending from the scapula to the right axilla. In one case (Patient 2) tracer uptake at the tumour site increases for at least 4 days. Tumour imaging was successful only if the lesions were greater than $2 \mathrm{~cm}$ in diameter. Radioactivity ratios in tumours compared with the contralateral normal tissue ranged from 1.2 to 1.6 and were confirmed by qualitative observations.

\section{Discussion}

Four of six patients with metastatic malignant melanoma who received ${ }^{111}$ In-radiolabelled LAK cells demon- 


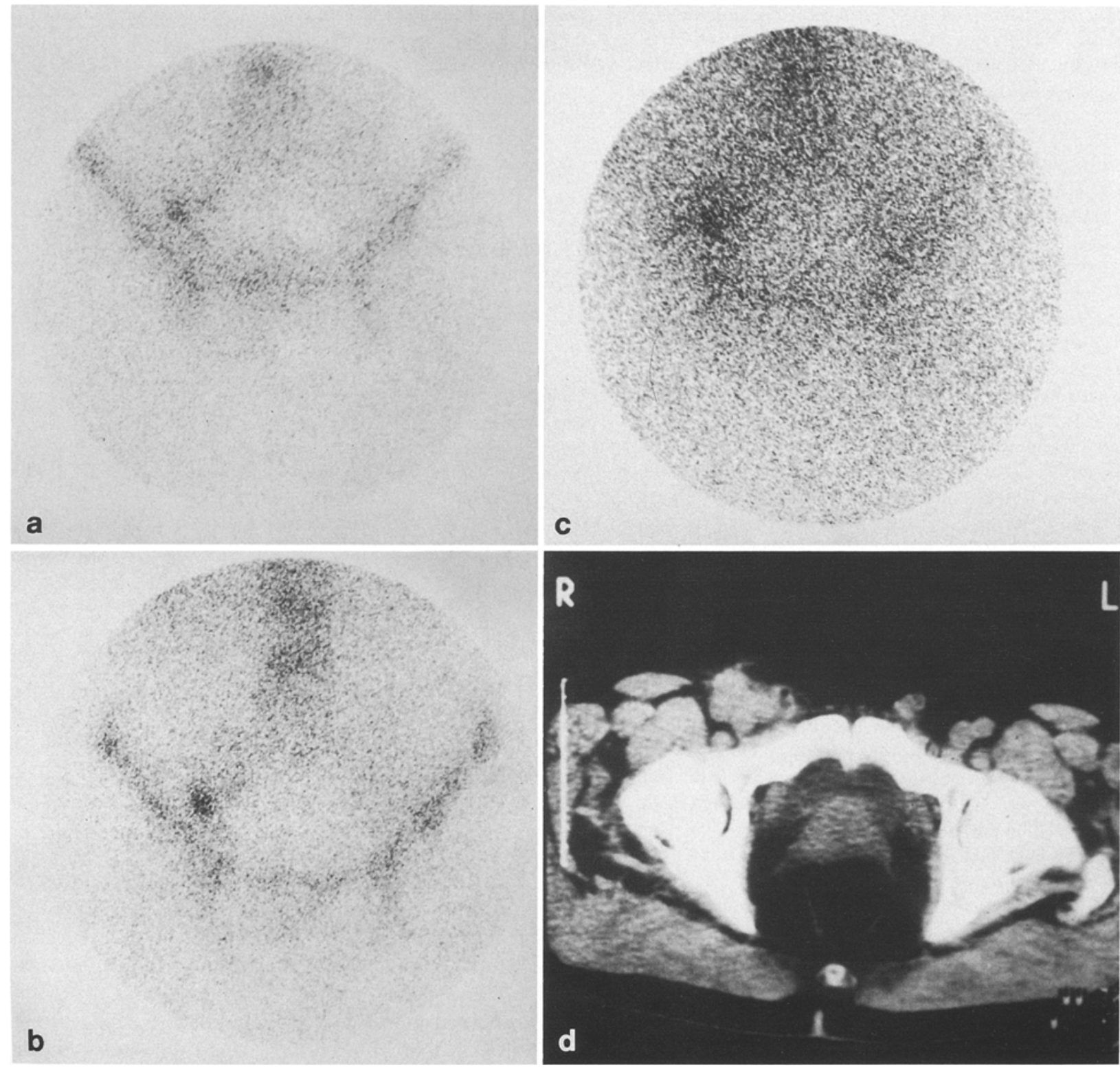

Fig. 1a-d. Kinetics of tumour localisation on serial scintiscans: a $2.5 \mathrm{~h}, \mathbf{b} 24 \mathrm{~h}, \mathrm{c} 48 \mathrm{~h}$ post-injection; d right inguinal tumour mass imaged by computed tomography

strated localisation of radioactivity at various tumour sites. All sites of increased uptake corresponded to lesions visible on $\mathrm{CT}$ scan or ultrasonic examination. The failure of tumour homing in our patients with lung and subcutaneous metastasis is possibly due to the small tumour size. The best tumour imaging was obtained between 24 and $48 \mathrm{~h}$. These late scans suggest recirculation of labelled lymphocytes.

In order to characterize LAK traffic and tumour localization, we applied the methods of others who had successfully labelled and trafficked normal lymphocytes (Lavender et al. 1977; Rannie et al. 1977; Wagstaff et al. $1981 \mathrm{a}$ ). Because of its half-life of 2.8 days, which is long enough for in vivo distribution studies, indium 111 is the isotope of choice for LAK labelling. Indium 111 ox- ine complex offers the advantage of easy penetration through cell membranes and binds tightly to cytoplasmic proteins; however, the cells have to be suspended in plasma-free media to protect the indium 111 label from loss to plasma transferrin (McAfee and Thakur 1976). Labelling should be limited to $0.4-0.7 \mathrm{MBq} / 10^{8}$ cells to avoid cellular damage (Chisholm et al. 1979). This condition can hardly be fulfilled without leucapheresis (Wagstaff et al. $1981 \mathrm{a}, \mathrm{b}$ ). Although there could be reservations concerning the detrimental effects of indium 111 labelling on lymphocytes, the increasing accumulation of activity at tumour sites suggests functional integrity of the re-transfused cells.

Ealier imaging studies with radiolabelled autologous LAK cells or lectin-activated killer cells failed to demon- 

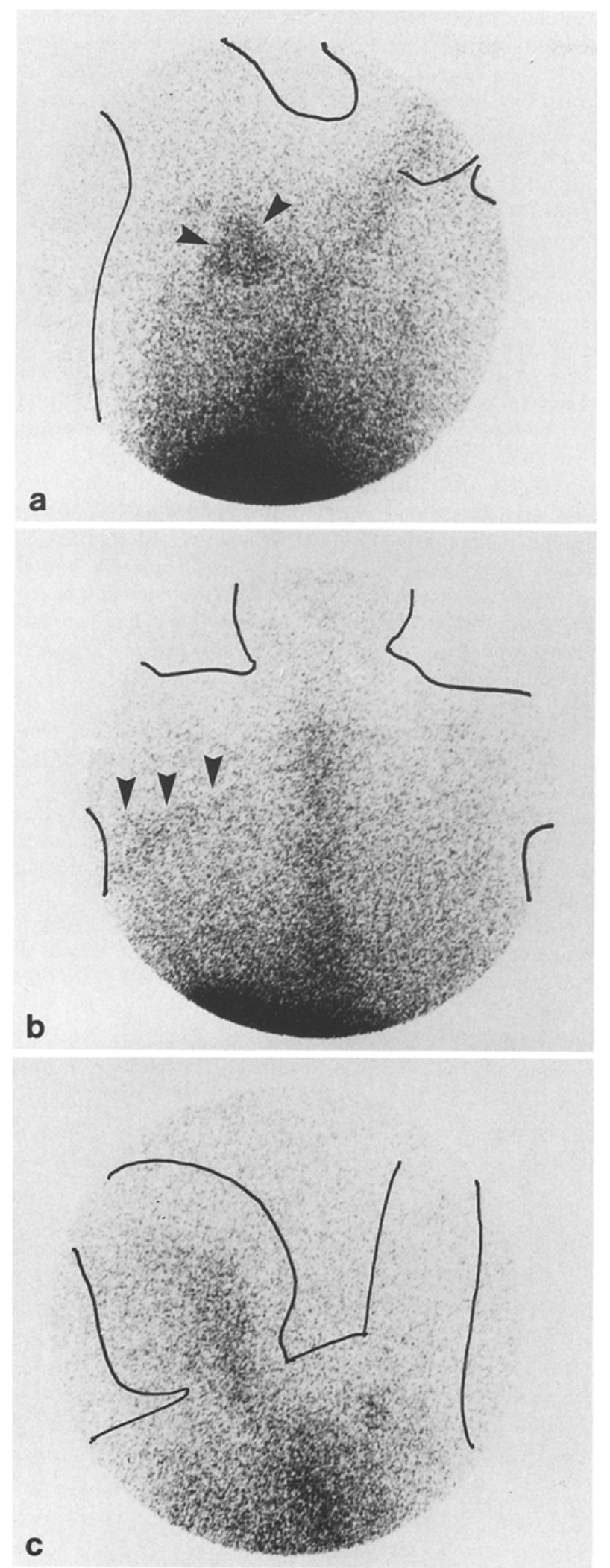

Fig. 2a-c. Involved right axillary lymph node chain imaged by ${ }^{111}$ In-radiolabelled lymphokine-activated killer cells $24 \mathrm{~h}$ after injection: a right oblique; $\mathbf{b}$ ventral; $\mathbf{c}$ left oblique strate consistent uptake at tumour sites. These cells preferentially localized to the lung, liver and spleen and appeared to be promptly removed from the circulation by the reticular-endothelial system. They exhibit the same unspecific migration as heat-damaged lymphocytes (Lotze et al. 1980; Mazumber et al. 1984; Mukherji et al. 1988), suggesting that they may have been damaged during labelling or infusion.

Another possible explanation of the lack of tumour homing in these previous studies is a suppressive activity, which was found in the sources of native IL-2. IL-2 (T-cell growth factor) used in early human studies was obtained from supernatants of peripheral blood mononuclear cells stimulated with phytohaemagglutinin alone or in combination with phorbol myristate acetate (Grimm et al. 1982). These supernatants were generally delectinated and partially purified to produce an IL-2enriched fraction, which contains a variety of other factors including IL-4. In fact, when this factor was present together with IL-2 from the beginning of the culture, the lytic activity that normally develops in cultures supplemented with IL-2 alone was almost totally inhibited (Widmer et al. 1987).

The distribution of peripheral blood lymphocytes sensitized against autologous tumour cells of various origins was studied by Mukherji et al. (1988). He found in four of seven patients that sensitized lymphocytes showed accumulation at metastatic sites. Only one of three patients with metastatic malignant melanoma demonstrated a positive imaging by injection of LAK cells.

More recently, Fisher et al. (1989) demonstrated the ability of TILs to traffic and localize in tumour sites. Six patients with malignant melanoma received cyclophosphamide $36 \mathrm{~h}$ before intravenous TIL infusion followed by IL- 2 injection every $8 \mathrm{~h}$. In all patients positive tumour imaging was achieved.

In another study tumour detection failed with ${ }^{111} \mathrm{In}$ labelled TILs with non-specific lytic activity in patients with metastatic adenocarcinoma of the lung (Kradin et al. 1987).

Our own results indicate that LAK cells are able to migrate to tumour sites. For this phenomenon no immunosuppression or additional IL-2 infusion is necessary. These data confirm the findings of Al Maghazachi et al. (1988) who showed that altering host immunity with irradiation, cyclophosphamide and/or administration of IL-2 in animals models did not alter the basic distribution pattern of LAK cells.

It is not clear yet whether the anti-tumour effect of LAK cells is mediated by indirect effects like induction of other cytokines or by direct, cell-mediated cytotoxicity. Tumour homing of LAK cells provides a direct interaction between cytotoxic lymphocyte and tumour cells which could be an important mechanism for tumour regression during therapy with IL-2 and LAK cells.

In summary, ${ }^{11}$ In-labelled LAK cells may be helpful for kinetic studies or detection of metastases in patients 
with malignant melanoma. Further investigations have to demonstrate whether LAK cell homing is a prognostic factor for immunotherapies using IL-2 with or without additional cell transfer.

Acknowledgements. We wish to thank I. Grelle, H. Jahn and C. Pietzsch for the skillful technical assistance.

\section{References}

Al Maghazachi A, Herberman RB, Vujanovic NL, Hiserodt JC (1988) In vivo distribution and tissue localization of highly purified rat LAK-cell. Cell Immunol 115:179-194

Chisholm PM, Danpuve HJ, Healey G, Osman S (1979) Cell damage from the labeling of rat thoracic duct lymphocytes and HeLa 53 cells with In-111 oxine. J Nucl Med 20:1308-1311

Fisher B, Packard BS, Read EJ, Carrasqoillo JA, Carter CS, Topalian SL, Young JC, Yolles P, Larson SM, Rosenberg SA (1989) Tumur localization of adoptively transferred indium-111 labeled tumor infiltrating lymphocyte in patients with malignant melanoma. J Clin Oncol 7:250-261

Kradin RL, Boyle LA, Preffer FI, Gallahan RJ, Barlai-Kovach M, Strauss HW, Dubinett S, Kurnick JT (1987) Tumor derived interleukin-2 dependent lymphocytes in adoptive immunotherapy of lung cancer. Cancer Immunol Immunother 24:76-85

Lavender JP, Goldman IM, Arnot RN, Thakur ML (1987) Kinetics of In 111 labeled lymphocytes in normal subjects and patients with Hodgkin's disease. Br Med J 2:797-799

Lotze MT, Line BR, Mathisen JK (1980) The in vivo distribution of autologous human and murine lymphoid cells grown in T-cell growth factor: implications for the adoptive immunotherapy of tumors. J Immunol 125:1487-1493

Mazumber A, Eberlein TJ, Grimm EA (1984) Phase 1 study of the adoptive immunotherapy of human cancer with lectin activated autologous mononuclear cells. Cancer 53:896-905

McAfee JG, Thakur ML (1976) Survey of radioactive agents for in vitro labeling of phagocytic leukocytes. Soluble agents. J Nucl Med 17:480-487

Mukherji B, Arnbjarnarson O, Spitznagle IA, Kalish RI, Hoffman J, Ergin MT, Spencer RP (1988) Imaging pattern of previously in vitro sensitized and interleukin-2 expanded autologous lymphocytes in human cancer. Nucl Med Biol 15:419-427

Rannie GH, Thakur ML, Ford WL (1977) An experimental comparison of radioactive labels with potential application to lymphocyte migration studies in patients. Clin Exp Immunol 29:509-514

Rosenberg SA, Lotze MT, Muul LM, Chang AE, Avis FP, Leitman S, Linehan WM, Robertson CN, Lee RE, Rubin JT, Seipp CA, Colleen RN, Simpson CG, White DE (1987) A progress report on the treatment of 157 patients with advanced cancer using lymphokine-activated killer cells and interleukin-2 or high dose interleukin-2 alone. N Engl J Med 316:889-897

Topalian SL, Solomon D, Avis FP, Chang AE, Freerksen DL, Linehan WM, Lotze MT, Robertson CN, Seipp CA, Simon P, Simpson CD, Rosenberg SA (1988) Immunotherapy of patients with advanced cancer using tumor infiltrating lymphocytes and recombinant interleukin-2; a pilot study. J Clin Oncol $6: 839-853$

Wagstaff J, Gibson C, Thatcher N, Ford WL, Sharma H, Benson W, Crowther D (1981a) A method for following human lymphocyte traffic using indium-111 oxine labelling. Clin Exp Immunol 43:435-442

Wagstaff J, Gibson C, Thatcher N, Ford WL, Sharma H, Crowther D (1981 b) Human lymphocyte traffic assessed by indium-111 oxine labelling: clinical observations. Clin Exp Immunol 43: $443-449$

Widmer MB, Acres RB, Sassenfeld HM, Grabstein KM (1987) Regulation of cytolytic cell populations from human peripheral blood by $\mathrm{B}$ cell stimulatory factor 1 (interleukin-4). J Exp Med 166:1447-1455 